\title{
Professor's Optimal Workload Problem and His Remunerations: A General Solution from Lagrangian Function
}

\author{
John Ogwang \\ Department of Business Management, Faculty of Management Sciences \\ Lira University - Uganda
}

\begin{abstract}
The author proposed a general solution to professor's optimal workload by using Lagrange method. University Management is treated as a utility maximizer, whose objective is to efficiently utilize professor's teaching hours and research output to the maximum level. The paper used the Cob-Douglas utility function for this utility maximization problem. The data used for this analysis were obtained from policy documents of Lira University and Makerere University in Uganda. The model generated varying maximum levels of teaching loads and research output for different categories of academic staff and faculties (Science and Non-science faculties). Generally, workload increases in both dimensions of teaching and research, as remuneration increases when one is promoted from a lower position, say a senior lecturer, to higher position, say Associate professor. The model also generated higher workload both in teaching and research for the Faculty (Sciences) whose academic staff are better paid compared to staff in the nonscience Faculty who are paid lower remunerations. The paper contributes to existing literature on Faculty workload model in two ways: Firstly, is the design of differential maximum workload system for different categories of Academic Staff depending on the level of their remunerations and seniority. Secondly, the decomposition of Academic staff's maximum workload into its teaching and research components for any given fixed amount of remuneration. The paper concludes by suggesting appropriate policy implications.
\end{abstract}

Key Words: Teaching Load, Research Publication, Remunerations, Lagrangian Function, Lira University, Makerere University

\section{Introduction}

Today, headlines such as, 'Faculty burnout', 'Moonlight professors', 'Academic Deadwood', dominate literature on provision of University education in Africa generally. Papers such as Nikolioudakis, Tsikliras, Somarakis, and Stergiou(2015), Lackritz (2004) and Ologunde, Akindele, and Akande, (2013), have analyzed the above phenomena in depth and provided useful recommendations. In brief, Faculty burnout is fatigue, frustration, or apathy suffered by a professor resulting from prolonged stress, overwork, or intense activity. Moonlight professors are professors who work at an additional job to their full time Faculty job, and Academic Deadwood relates to research inactive professors. Intuitively, central ideas behind the above phenomena are workload and remuneration of Academic staff (professors) which in a broader context, can be summarized as professors' welfare issues.

University Academic Staff Unions in many countries have always engaged their respective governments to address critical issues related to academic staff welfare (professors' welfare) through signing the Collective Bargaining Agreements between Academic Staff Unions and Government. In some cases, University Academic staff would go on strike as an ultimate weapon for the Faculty staff against unfair academic policies (Collins, 2003). Faculty strikes arising from issues of remunerations and workload are emerging trends in the annals of University Education training and may have devastating effects on the quality of higher education in Africa generally.

The General Conference of the United Nations Educational, Scientific and Cultural Organization (UNESCO), in Paris from $21^{\text {st }}$ October to $12^{\text {th }}$ November 1997 , at its 29 th session was very critical on this kind of phenomenon, and indeed, its recommendations number $57-64$ provide useful international guidelines on terms and conditions of employment of lecturers in institutions of higher education, specifically on matters of remuneration, workload, social security benefits, and safety. While the issue of remuneration has been the key factor in many public universities, as noted by Owuor (2012), workload for lecturers and abnormal Lecturer - Students ratio are also other factors affecting the quality of higher education specifically in Kenya. In Uganda, the National Council for Higher Education (NCHE) Quality Assurance Framework and Licensing Process (2014) stipulates the ideal workload in terms of contact hours for lecturers to be $10 \mathrm{hrs}$ per week, and it suggests that a workload of up to 30 contact hours/week can still be improvable. According to that framework, a teaching load which is over 30 contact hours is unacceptable. The Framework, however, does not say anything about professor's workload arising from other duties such as research, administration and community services. 
University academic staff, here generally referred to as professors, perform two cardinal functions of: (1) Increasing current knowledge through research and (2) to spread this knowledge to the new generation through teaching. The emphasis on research roles of a professor makes a professor different from a teacher. According to Martin (2012), research and teaching functions of a professor complement each other, that is, teaching can be more efficient after some research is done by professor and vise-versa. Other duties of a professor, to a lesser extent, include administrative works and community services. In this paper, the author analyzed professor's workload in terms of his teaching hours and research output, while taking into account his fixed remunerations. Uganda and Sub Saharan African Universities generally have a much skewed contribution to the global research output. According to World Bank and Elsevier (2014), the total contribution of Sub Saharan African to the global Research Output of $0.72 \%$ is alarmingly low. Moreover, countries with comparable research output such as Malaysia and Vietnam realized a higher growth in their research output over the period from 2002 - 2012 than growth in scientific research in Sub- Saharan African countries. Existing literature on higher education management properly acknowledges the roles of Universities in creating knowledge through research and disseminating knowledge to young generation through teaching. However, there is no evidence in literature that economists have proposed asa reliable technique of breaking down professor's total workload into its teaching and research components, when his remuneration is fixed at some amount. The only paper which tries to investigate how to achieve the appropriate balance between teaching and research is Khan (2017) which uses an exploratory study. The paper shows a very serious imbalance between teaching and research in universities, with some universities focusing much on teaching, while others focusing much on research. As noted by Muriisa (2015), some Universities are ceasing to do research and have become teaching factories.

This paper contributes to existing literature on Faculty workload models in the following ways: Firstly, using an appropriate quantitative model, the paper suggests that professor's remunerations and his workload are inseparable. Any increase in professor's remuneration must incorporate professor's workload adjustment, when other economic factors like inflation are held constant, unless that pay rise is not based on economic reason. For this reason, the novelty of the paper is the design of the differential maximum workload system for different categories of professors depending on the level of their remunerations and seniority. Secondly, the novel idea is the decomposition ofprofessor'smaximum workload into its teaching and research components at any given fixed amount of remuneration using a reliable theoretical economic model. In the next chapter of literature review, it can be confirmed that existing literature on Faculty workload models has not addressed these two issues.

\section{Literature Review}

Literature on higher education in Africa generally, and Uganda in particular, with a major focus on Universities is growing although it is still scanty. Mushemeza (2016) studied the opportunities and challenges of staff in Higher Education and noted that poor remuneration was one of the challenges facing staff of Higher Education Institutions in Africa. The paper further recommended that the recruitment, promotion, and appointment of staff should be based on their productivity. The paper however, did not link staff productivity (workload) to their remuneration. Similarly, Basarudin, Yeon, Yaacob, and Rahman (2016) investigated the Faculty workload and their benefits in public universities in Malaysia and found that the workload of academic staff was not proportionate to the benefits they derived. That is, professors benefited less from their involvement in teaching, research and community outreach activities. The reason for this was that Government of Malaysia had set very high performance standard for professors in order to cope with international standard and as such, professors had to overwork in order to meet that standard. The paper also noted that professor's workload varies according to the Faculty, that is, professors in some Faculties have more workload than their colleagues in other Faculties. The paper however, did not quantify the gap between professor's workload and the benefits they derived (remunerations). A study of how a University professor should be rewarded based on performance was conducted by Rubenstein (2000). The paper found that in general, it is difficult to identify and reward Canadian professors, who perform above the average, or to identify and sanction low performers. The paper however, highlighted a very important practice at University of Manitoba by that time, where professors who chose not to do research and concentrated only on teaching, even if they were very mighty in classroom teaching and pedagogical issues, they would be punished by having their teaching load doubled, or have their remunerations reduced by at least $50 \%$. As noted by Yates (2012), over the last twenty years, both small and medium size universities have been moving from being teaching universities, to involving their professors in more rigorous research but without reducing professors' teaching workload.

Recent dialogue regarding the place of universities in a "knowledge society" has not necessarily reflected the impact on the workloads of faculty given the increased expectations for measurable outputs, responsiveness to societal and student needs, and overall performance accountability (Houston, Meyer and Paewai2006). 
A study of academic workload for professors at two regional Australian Universities was conducted by Dobele, Thiele, Kopanidis, and Steel, (2010). The paper found that university that is over represented by female in senior academic position achieved equity in workload. Conversely, Universities that are underrepresented with females in senior academic positions do not achieve workload equity, with male academics producing more research and coordinating more teaching. Kim and Rehg (2018) investigated Faculty performance and morale in Higher Education using a system approach and pointed out many important issues. Specifically, they found that the weights which Faculty staff assign to teaching and research will change depending on the institution type (research university or teaching university) and their roles (whether they are fulltime staff or temporarily hired), and that the workload of professors will be influenced directly by the increase in students enrolment. According to Kim and Rehg (2018), the high Faculty workload would lead to the Faculty burnout which in turn leads to decline in student-faculty interaction, which ultimately leads to decline in professor's performance. As their performance declines, they become demoralized and the low morale finally leads to the Faculty turnover. As defined in Minter (2009), Faculty burnout is the lack of desire and motivation to achieve a balance among professorial responsibilities in the areas of: teaching, scholarship, service, and student caregiving and peer relationships.

\section{Methodology}

\section{Data}

The analytical model used in this paper requires that the following parameters should be known or be estimated accurately: (1) Wage rate per hour (price of one hour of teaching), (2) the cost of publishing a paper (the price that the University pays a professor for publishing one paper), (3) the weight that the university attaches to research relative to teaching, (4) the weight that the University attaches to teaching relative to research, and (5) Salary scale for different categories of Academic Staff.All the above parameters except the second one, were estimated from data obtained from policy documents of Lira University, one of the youngest public university in Northern Uganda and Makerere University. Makerere University was chosen because it is the country's oldest university, and in most cases all the upcoming Universities use it as the benchmark for best practices. Moreover, many universities in Uganda, especially public universities have similar structure of remuneration, policy framework and mandates, therefore, these two public Universities can provide a good representation of all public Universities, at least as far as this analysis is concerned.

\section{The Model}

Previous research on how to model professor's workload have been primarily based on two main approaches: firstly the use ofself-reporting measures (Okpara, Squillace, \& Erondu, 2005,) and secondly, reliance on qualitative research approach through interviews (Basarudin, Yeon, Yaacob, and Rahman 2016). In this paper, the approach is not qualitative. The author estimated the optimal number of teaching hours for professors and the optimal number of publications they should publish in the top 25\% ( $1^{\text {st }}$ quartile) of journals indexed in Web of Science using the Lagrangian function. The problem is treated as a constrained optimization case where University management seeks to maximize professor's teaching hours and the number of publications subject to the maximum remuneration that the university is willing to pay professor. The paper utilizes Cob-Douglas utility function subject to the budget constraint (fixed remuneration) to solve this utility maximization problem. As noted by Hughes (2012), Cob-Douglas utility function yields a well behaved utility function, and in a two dimensional space, the utility curve will be downward sloping. The marginal rate of substitution between the two variables (in this case, teaching hours and the number of publications) will also be diminishing. The Marginal Rate of Substitution dependsupon the ratio of the choice variables but not on the budget. This assumption seems to be very realistic given the nature of university's mandate to conduct teaching and research. The behaviour of Cob-Douglas utility function implies that any decrease or increase in professor's remuneration must not alter the proportion of teaching and research components of professor's total workload. That is, at a lower remuneration, it would be unrealistic for a professor to say he is only going to teach and sacrifice research, or at a higher salary, he is going to concentrate more on research at the expense of teaching. The model appears in the form below:

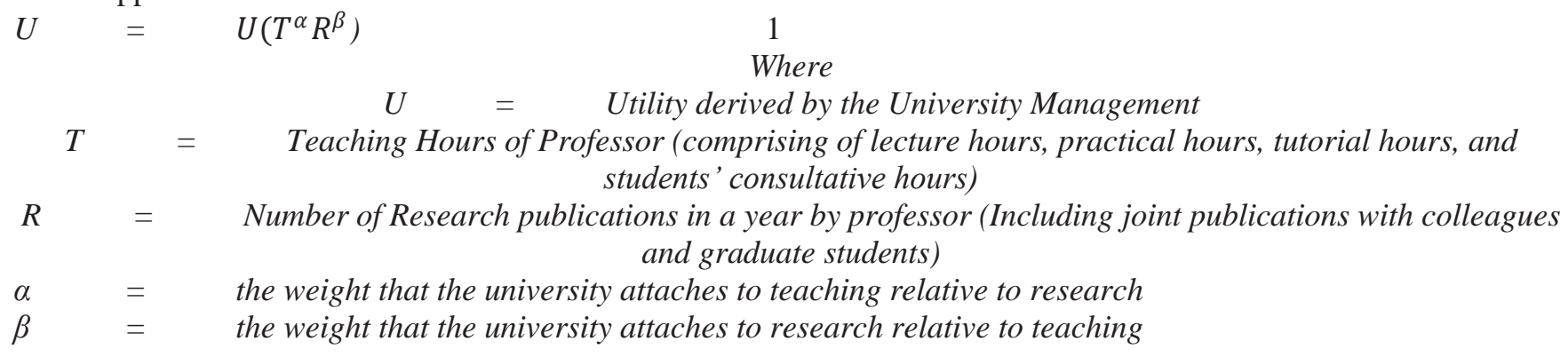


For Lira University, Parameters $\alpha$ and $\beta$ were estimated from the budgetary allocation for teaching and research in Lira University Strategic plan 2016 - 2021. From the approved strategic plan for Lira University for the financial year $2018 / 2019$, the budgetary allocationto promote Research, Innovation and publication is UGX 629,200,000 and the corresponding budgetary allocation for teaching and training is UGX 6,636,880,000. Therefore, $\beta=$ $\frac{629,200,000}{629,200,000+6,636,880,000}=0.0866$ and $\alpha=\frac{6,636,880,000}{629,200,000+6,636,880,000}=0.9134$.

For Makerere University, these parameters were estimated from the weights in hours that University attaches to teaching and research activities. This information was obtained from Makerere University Staff recruitment and promotion policy (2006) as amended in 2009. From that policy document, the total hours for research related activities was estimated to be 8 hours (research + supervision). While the total hours for teaching activities included Lecturing, Tutorial, Marking, and Practical $(6+2+6+2=16 \mathrm{hrs})$. The hours for lecture preparation were excluded because it is not observable in most cases. Therefore, the weight for teaching, $\alpha=16 / 24$, and the weight for research, $\beta=8 / 24$

\section{Table 1: Distribution of work load in hours for various academic activities in Makerere University}

\begin{tabular}{lr}
\hline Activity & Hours \\
\hline Lecture Preparation & 12 \\
Lecturing & 6 \\
Tutorial/Seminar & 2 \\
Marking & 6 \\
Practical/Clinical & 2 \\
Supervision & 4 \\
Research & 4 \\
\hline
\end{tabular}

Source: Makerere University Policy on Appointment and Promotion (2006) as amended 2009

The above distribution of workload was used to estimate the weight $\alpha$ that the University attaches to teaching and the weight $\beta$ that the University attaches to research. The total hours for research related activities were estimated to be 8 hours (research + supervision). While the total hours for teaching activities included Lecturing, Tutorial, Marking, and Practical $(6+2+6+2=16 \mathrm{hrs})$. Lecture preparation was excluded because it is not observable in most cases. Therefore, the weight for teaching, $\alpha=16 / 24$, and the weight for research, $\beta=8 / 24$

The sum of these weights equals one. That is:

$\alpha+\beta=12$

University Management maximizes equation 1 subject to the budget constraint:

$P_{r} R+P_{t} T=S 3$

$P_{t} \quad=\quad$ wage rate per teaching hour

$P_{r} \quad=$ cost per research publication (paid by the university to a professor for publishing a paper)

$S=\quad$ Remuneration earned by the professor (monthly or annualized net of tax)

The hourly wage rate, $P_{t}$ for teaching was estimated based on the standard set by National Council for Higher Education in Uganda.National Council for Higher Education (NCHE) Quality Assurance Framework and Licensing Process (2014) stipulates the ideal teaching load in terms of contact hours for lecturers to be $10 \mathrm{hrs}$ per week, the teaching load of 15 contact hours is considered good, 20 contact hours is acceptable , 30 contact hours can still be improved, and more than 30 contact hours is unacceptable. As indicated in many literature on standard costing and variance analysis, ideal standards can only be achieved under the perfect operating conditions, hence the author used 15 hours weekly teaching load to estimate wage rate per teaching hour. The weekly teaching load of 15 hours is realistic because the teaching load of academic staff is currently within this range.Hence in a month, a professor is expected to teach for 60 hours $(15 \mathrm{hrs} \times 4)$. His monthly remuneration, Sdivided by 60 hours gives an approximation for thewage rate per teaching hour $P_{t}$. The base monthly salary net of tax for Teaching Assistant was used to estimate the wage rate per hour as follows: Wage rate per hour taught,$P_{t}=\frac{S}{60 \text { Hours }}=\frac{3,224,295}{60 \text { Hours }}=U G X$ 53,738 per hr. This rate is realistic in the sense that it is closer to the market rate that many Universities in Uganda are currently paying their Academic staff for parttime teaching.

The challenge with this approximation of $P_{t}$ is that it assumes that the total remuneration, $S$ paid to a professor is only meant for teaching but not research. However, the following reasons justify why we should assume that the monthly remuneration earned by a professor in Uganda University is substantially meant for teaching:

1. When a professor absconds from teaching for the whole month, the whole remuneration, $S$ is always withheld even if that professor has published some papers within that month. 
2. Even if a professor does not publish for the whole year, he is paid a full remuneration; $S$ provided he had taught his entire teaching load. So far there is no evidence that any professor (Academic staff) in Uganda public universities is paid partial salary for failing to publish.

3. Many Universities in Uganda including Lira University use research output for purposes of promotion and hence research outputs are not closely linked to monthly remuneration of professors.

It is difficult to estimate the cost per research publication (the amount the university pays a professor for publishing a research paper) because of data limitations. Since Uganda and some South East Asian countries have the same comparable level of academic research output (World Bank 2014), some practices from Malaysian Universities is adopted. University of Malaya pays RM 2,000 equivalent to UGX $1,600,000$ per publication in the top $25 \%\left(1^{\text {st }}\right.$ quartile) of journals indexed in Web of Science. So we take $P_{r}$ to be UGX 1600,000. Finally, remuneration Searned by a professor, monthly or annualized and net of tax was obtained from the recent salary structure for different categories of academic staff in Uganda public Universities. Table 2 presents the details of this salary structure for both science and non-science academics.

Table 2: Salary Structure of Academic Staff of Public Universities in Uganda in year 2018/2019

\begin{tabular}{lccr}
\hline Staff Category & Per Month & Per Annum & $\begin{array}{r}\text { Annual Remuneration Net of 30\% } \\
\text { Tax }\end{array}$ \\
\hline Sciences & & & \\
Professor & $9,150,286$ & $109,803,432$ & $76,862,402$ \\
Assoc. Professor & $8,586,787$ & $103,041,444$ & $72,129,011$ \\
Senior Lecturer & $7,725,507$ & $92,706,084$ & $64,894,259$ \\
Lecturer & $7,013,324$ & $84,159,888$ & $58,911,922$ \\
Assistant Lecturer & $5,237,649$ & $62,851,788$ & $43,996,252$ \\
Teaching Assistant & $4,606,136$ & $55,273,632$ & $38,691,543$ \\
Non-Science & & & \\
Professor & $8,100,023$ & $97,200,276$ & $68,040,193$ \\
Assoc. Professor & $7,798,835$ & $93,586,020$ & $65,510,214$ \\
Senior Lecturer & $7,118,538$ & $85,422,456$ & $59,795,719$ \\
Lecturers & $6,528,695$ & $78,344,340$ & $54,841,038$ \\
Assistant Lecturer & $4,660,161$ & $55,921,932$ & $39,145,352$ \\
Teaching Assistant & $3,775,047$ & $45,300,564$ & $31,710,395$ \\
\hline
\end{tabular}

Collective Bargaining Agreement between Government of Uganda and University Professionals and Academic Staff Union (UPASU) on $2^{\text {nd }}$ June, 2018 agreed on the above salary structure for academic staff in Uganda public Universities. Optimal teaching load and publications were estimated on the basis of annual remuneration net of $30 \%$ tax. The figures are on the last column of table 2. Remunerations net of tax was used because this is the take home amount which determines the decision as to whether the worker should continue with the work or quit.

With those five parameters $\left(\alpha, \beta, P_{t}, P_{r}\right.$ and $\left.\mathrm{S}\right)$ readily estimated, the next step is to introduce the Langragian function as follows:

$$
\mathrm{Z}=T^{\alpha} R^{\beta}+\lambda\left(\mathrm{S}-P_{r} R-P_{t} T\right)
$$

4

Where $\lambda=$ the Langragianmultiplier. Since monotonic transformation of the Cob-Douglas utility function using logarithms would not alter the turning point of the utility function,

$\mathrm{Z}=\alpha \ln \mathrm{T}+\beta \ln \mathrm{R}+\lambda\left(\mathrm{S}-P_{r} R-P_{t} T\right) 5$

The parameter $\lambda$ in equation 5 measures the marginal utility of professor's salary. We take the First Order Condition as follows:

$$
\begin{aligned}
& \frac{\partial \mathrm{Z}}{\partial T}=\frac{\alpha}{T}-\lambda P_{t}=0 \\
& \frac{\partial \mathrm{z}}{\partial R}=\frac{\beta}{R}-\lambda P_{R}=0 \\
& \frac{\partial \mathrm{z}}{\partial \lambda}=\mathrm{S}-P_{r} R-P_{t} T=0
\end{aligned}
$$

Solving equation 6 and 7 yields the following optimal level of the number of publications in the year as shown in equation 9. Equation 9 also gives the Marshalian demand function for research by the University Management.

$R^{*} \quad=\quad \frac{\beta P_{t} T}{\alpha P_{r}} 9$

Substituting for $R^{*}$ in equation yields equation 10 , which gives an optimal number of teaching hours that a professor can teach in a year. Equation 10 also gives the Marshalian demand function for teaching hours in the University. 
$T^{*} \quad=\quad \frac{\alpha S}{P_{t}} \quad 10$

More so, with those information available, the amount of total remuneration, $S$ attributable to teaching, denoted by $S_{t}$ and that attributable to research, $S_{r}$ can be obtained. This can help management to take appropriate actions such as withholding a right proportion of remuneration in case a professor does not perform up to expectation on any of the two decision variables (Teaching hours and training). It follows that: $\mathrm{S}=S_{t}+S_{r}$ where $S_{t}=$ wage rate per teaching hour $\left(P_{t}\right) \times$ Number of hours taught $(T)$ and $S_{r}=$ Cost per research publication $\left(P_{r}\right) \times$ the number of publications $(R)$. It should be noted that:

$\begin{array}{llll}\frac{P_{r} R}{S_{r}+S_{t}}=\frac{S_{r}}{S}=\beta & 11 & \\ \frac{P_{t} T}{S_{r}+S_{t}}=\frac{S_{t}}{S}=\alpha & \alpha & 12\end{array}$

Equations 11 and 12 show that the weight, $\beta$ that university attaches to research is equivalent to the proportion of professor's total salary, $S$ that is attributable to research and the weight, $\alpha$ that the university attaches to teaching is equivalent to the proportion of professor's total salary attributable to teaching.

\section{Results}

Results for the maximum teaching hours per year, month, and week and the maximum number of publications per year, for professors, Associate professor, senior lecturers, lecturers, Assistant lecturer and Teaching Assistants are presentedin table 3. Results generated by the model are very interesting. It is apparent that the workload for a professor increases in both dimensions of teaching hours and Research publications as the level of seniority of the professor increases. As one progresses from the lowest position of Teaching Assistant to the highest position of the full professor, his workload subsequently increases. This is in the spirit of Mushemeza (2016) who argued that promotion of Academic staff in University should be based on productivity. In other words, a full professor should be more productive than a senior lecturer and as such, he should publish more papers and take more hours teaching and mentoring junior staff like teaching assistants, by spending time with them as they teach. The teaching load and publications for science professors are also more than the loads for non-science professors. This is for obvious reasons that Science professors have extra contact hours with students in laboratory and field work, and moreover, in most cases, they engage in applied research which are easily publishable. The increased workload for science professors is due to the view that their remunerations are also higher. This result confirms Basarudin et al. (2016) which found that workload varies across Faculties in Malaysian Universities. As noted earlier, the total teaching hours for professor includes lecture hours, practical hours, Tutorial hours for mentoring junior staff and consultative hours for students. According to this model, the maximum teaching hours for a science professor at Lira University should be 27 hours per week, and the maximum teaching hour for a teaching Assistant should be 14 hours per week. Therefore, using the minimax criteria, the minimum maximum number of teaching hours for an Academic staff at Lira University should be 14 hours. Conversely, a professor having such a high teaching load would publish only a maximum of 4.15 papers a year, and a teaching assistant would publish about two papers a year. The mean maximum teaching load for all categories of academic staff would be 21.16 hours per week for the science professor at Lira.

Table 3: Workload Summary and Remunerations for Science Professors - Lira University

\begin{tabular}{|c|c|c|c|c|c|c|c|}
\hline Title & $\begin{array}{l}\text { Annual } \\
\text { Teachin } \\
\text { g Load }\end{array}$ & $\begin{array}{l}\text { Monthly } \\
\text { Teachin } \\
\text { g Load }\end{array}$ & $\begin{array}{l}\text { Weekly } \\
\text { Teachin } \\
\text { g Load }\end{array}$ & $\begin{array}{l}\text { No. of } \\
\text { Publicatio } \\
n \text { per Year }\end{array}$ & $\begin{array}{l}\text { Annual } \\
\text { Remuneratio } \\
\mathrm{n}\left(S_{t}\right) \\
P_{t} \times T\end{array}$ & $\begin{array}{l}\text { Annual } \\
\text { Remuneratio } \\
\mathrm{n}\left(S_{r}\right) \\
P_{r} \times R\end{array}$ & $\begin{array}{l}\text { Total } \\
\text { Remuneration } \\
S\end{array}$ \\
\hline \multicolumn{8}{|l|}{ Sciences } \\
\hline Professor & 1306 & 109 & 27 & 4.15 & $70,181,828$ & $6,640,000$ & $76,820,828$ \\
\hline $\begin{array}{l}\text { Assoc. } \\
\text { Prof }\end{array}$ & 1225 & 102 & 26 & 3.87 & $65,829,050$ & $6,192,000$ & $72,021,050$ \\
\hline $\begin{array}{l}\text { Senior. } \\
\text { Lecturer }\end{array}$ & 1103 & 92 & 23 & 3.51 & $59,273,014$ & $5,616,000$ & $64,889,014$ \\
\hline Lecturer & 1001 & 83 & 21 & 3.18 & $53,791,738$ & $5,088,000$ & $58,879,738$ \\
\hline $\begin{array}{l}\text { Assistant } \\
\text { Lecturer }\end{array}$ & 748 & 62 & 16 & 2.38 & $40,196,024$ & $3,808,000$ & $44,004,024$ \\
\hline $\begin{array}{l}\text { Teaching } \\
\text { Assistant }\end{array}$ & 658 & 56 & 14 & 2 & $35,359,604$ & $3,200,000$ & $38,559,604$ \\
\hline
\end{tabular}


Table 3 shows the maximum annual, monthly, and weekly teaching load and the maximum number of publications for different categories of science Academic staff at Lira University. Example an Associate Professor should teach for a maximum of 26 hours per week and publishes a maximum of 3.87 papers in a year. The proportion of his total remuneration attributable to teaching, $\left(\mathrm{S}_{\mathrm{t}}\right)$ is UGX 65,829,050 per year and that attributable to research $\left(\mathrm{S}_{\mathrm{r}}\right)$ is $6,192,000$ to give his total remuneration of UGX 72,021,050 per year.

Conversely, Science professors at Makerere University working for the same level of remuneration would teach for a maximum of 958 hours in a year and 19.9 hours in a week. However, each of them would publish a maximum of 15.85 papers in a year. A teaching Assistant of science at Makerere University would teach for a maximum of 482 hours a year, equivalent to a maximum of 10 hours a week and can publish a maximum of 8 papers in a year. Refer to table 4 for the teaching loads and the number of maximum number of publications for other categories of Academic staff in a science Faculty. The average teaching load for science lecturers at Makerere should therefore be 15.2 hours per week and the minimum maximum teaching load per week is 10 hours (For a Teaching Assistant)

Table 4: Workload Summary and Remunerations for Science Professors - Makerere University

\begin{tabular}{|c|c|c|c|c|c|c|c|}
\hline Title & $\begin{array}{l}\text { Annual } \\
\text { Teachin } \\
\text { g Load }\end{array}$ & $\begin{array}{l}\text { Monthly } \\
\text { Teachin } \\
\text { g Load }\end{array}$ & $\begin{array}{l}\text { Weekly } \\
\text { Teachin } \\
\text { g Load }\end{array}$ & $\begin{array}{l}\text { No. of } \\
\text { Publicatio } \\
n \text { per Year }\end{array}$ & \begin{tabular}{l}
\multicolumn{1}{c}{ Annual } \\
Teaching \\
Remuneratio \\
$\mathrm{n}\left(S_{t}\right)$ \\
$P_{t} \times T$ \\
\end{tabular} & $\begin{array}{l}\text { Annual } \\
\text { Research } \\
\text { Remuneratio } \\
\mathrm{n}\left(S_{r}\right) \\
P_{r} \times R \\
\end{array}$ & $\begin{array}{l}\text { Total } \\
\text { Remuneration } \\
S\end{array}$ \\
\hline \multicolumn{8}{|l|}{ Sciences } \\
\hline Professor & 958 & 79.8 & 19.9 & 15.85 & $51,481,004$ & $25,360,000$ & $76,841,004$ \\
\hline $\begin{array}{l}\text { Assoc. } \\
\text { Prof }\end{array}$ & 899 & 74.9 & 18.7 & 14.8 & $48,310,462$ & $23,680,000$ & $71,990,462$ \\
\hline $\begin{array}{l}\text { Senior. } \\
\text { Lecturer }\end{array}$ & 809 & 67 & 16.8 & 13 & $43,474,042$ & $20,800,000$ & $64,274,042$ \\
\hline Lecturer & 734 & 61 & 15 & 12 & $39,443,692$ & $19,200,000$ & $58,643,392$ \\
\hline $\begin{array}{l}\text { Assistant } \\
\text { Lecturer }\end{array}$ & 548 & 45 & 11 & 9 & $29,448,424$ & $14,400,000$ & $43,848,424$ \\
\hline $\begin{array}{l}\text { Teaching } \\
\text { Assistant }\end{array}$ & 482 & 40 & 10 & 8 & $25,901,716$ & $12,800,000$ & $38,701,716$ \\
\hline
\end{tabular}

Table 4 shows the maximum annual, monthly, and weekly teaching load and the maximum number of publications for different categories of science Academic staff at Makerere University. Example, an Assistant Lecturer should teach for a maximum of 11 hours per week and publishes a maximum of 9 papers in a year. The proportion of his total remuneration attributable to teaching, $\left(S_{t}\right)$ is UGX 629,448,424 per year and that attributable to research $\left(S_{r}\right)$ is $14,400,000$ to give his total remuneration of UGX 43,848,424 per year net of tax.

A non-Science full Professor at Lira University should teach a maximum of 1156 hours in a year, 96 hours a month, and a weekly maximum teaching load of 24 hours. The maximum number of publications that he can publish in a year is 3.68. Similarly, a Teaching Assistant in a non-Science Faculty at Lira University would teach a maximum of 11 hours in a week and should produce a maximum of 1.71 publications in a year. The mean maximum teaching load per week across all categories of staff is 18.6 hours per week. 
Table 5: Workload Summary and Remunerations for Non-Science Professors - Lira University

\begin{tabular}{|l|l|l|l|l|l|l|l|}
\hline Title & $\begin{array}{l}\text { Annual } \\
\text { Teachin } \\
\text { g Load }\end{array}$ & $\begin{array}{l}\text { Monthly } \\
\text { Teachin } \\
\text { g Load }\end{array}$ & $\begin{array}{l}\text { Weekly } \\
\text { Teachin } \\
\text { g Load }\end{array}$ & $\begin{array}{l}\text { No. of } \\
\text { Publication } \\
\text { per Year }\end{array}$ & $\begin{array}{l}\text { Annual } \\
\text { Teaching } \\
\text { Remuneratio } \\
\mathrm{n}\left(S_{t}\right) \\
P_{t} \times T\end{array}$ & $\begin{array}{l}\text { Annual } \\
\text { Research } \\
\text { Remuneratio } \\
\mathrm{n}\left(S_{r}\right) \\
P_{r} \times R\end{array}$ & $\begin{array}{l}\text { Total } \\
\text { Remuneratio } \\
\mathrm{n} \text { S(Net of } \\
\text { tax) }\end{array}$ \\
\hline $\begin{array}{l}\text { Non } \\
\text { Science }\end{array}$ & & & & & & & \\
\hline Professor & 1156 & 96 & 24 & 3.68 & $62,121,128$ & $5,888,000$ & $68,009,128$ \\
\hline $\begin{array}{l}\text { Assoc. } \\
\text { Prof }\end{array}$ & 1113 & 93 & 23 & 3.54 & $59,810,394$ & $5,664,000$ & $65,474,394$ \\
\hline $\begin{array}{l}\text { Senior. } \\
\text { Lecturer }\end{array}$ & 1016 & 85 & 21 & 3.23 & $54,597,808$ & $5,168,000$ & $59,765,808$ \\
\hline Lecturer & 932 & 78 & 19 & 2.96 & $50,083,816$ & $4,736,000$ & $54,819,816$ \\
\hline $\begin{array}{l}\text { Assistant } \\
\text { Lecturer }\end{array}$ & 665 & 55 & 14 & 2.11 & $35,735,770$ & $3,376,000$ & $39,111,770$ \\
\hline $\begin{array}{l}\text { Teaching } \\
\text { Assistant }\end{array}$ & 538 & 45 & 11 & 1.71 & $28,911,044$ & $2,736,000$ & $31,647,044$ \\
\hline
\end{tabular}

Table 5 shows the maximum annual, monthly, and weekly teaching load and the maximum number of publications for different categories of non -science Academic staff at Lira University. Example, a senior Lecturer should teach for a maximum of 21 hours per week and publishes a maximum of 3.23 papers in a year. The proportion of his total remuneration attributable to teaching, $\left(S_{t}\right)$ is UGX 54,597,808 per year and that attributable to research $\left(S_{r}\right)$ is $5,168,000$ to give his total remuneration of UGX59, 765,808per year.

Conversely, a non-Science professor at Makerere University should teach a maximum of 18 hours a week with a maximum of 14 publications a week. A non-Science Teaching Assistant in Makerere University should teach for a maximum of 8 hours a week with a maximum publication of 6 papers a year. The mean maximum teaching load per week across all categories of non-science academic staff at Makerere University is 11.46 hours.

Table 6: Workload Summary and Remunerations for Non-Science Professors - Makerere University

\begin{tabular}{|c|c|c|c|c|c|c|c|}
\hline Title & $\begin{array}{l}\text { Annual } \\
\text { Teachin } \\
\text { g Load }\end{array}$ & $\begin{array}{l}\text { Monthly } \\
\text { Teachin } \\
\text { g Load }\end{array}$ & $\begin{array}{l}\text { Weekly } \\
\text { Teachin } \\
\text { g Load }\end{array}$ & $\begin{array}{l}\text { No. of } \\
\text { Publicatio } \\
n \text { per Year }\end{array}$ & $\begin{array}{l}\text { Annual } \\
\text { Teaching } \\
\text { Remuneratio } \\
\mathrm{n}\left(S_{t}\right) \\
P_{t} \times T \\
\end{array}$ & $\begin{array}{l}\text { Annual } \\
\text { Research } \\
\text { Remuneratio } \\
\mathrm{n}\left(S_{r}\right) \\
P_{r} \times R \\
\end{array}$ & $\begin{array}{l}\text { Total } \\
\text { Remuneration } \\
S\end{array}$ \\
\hline $\begin{array}{l}\text { Non } \\
\text { Sciences }\end{array}$ & & & & & & & \\
\hline Professor & 848 & 71 & 18 & 14 & $45,569,824$ & $22,400,000$ & $67,969,824$ \\
\hline $\begin{array}{l}\text { Assoc. } \\
\text { Prof }\end{array}$ & 816 & 68 & 17 & 13.5 & $43,850,208$ & $21,600,000$ & $65,450,208$ \\
\hline $\begin{array}{l}\text { Senior. } \\
\text { Lecturer }\end{array}$ & 745 & 62 & 15.8 & 12 & $40,034,810$ & $19,200,000$ & $59,234,810$ \\
\hline Lecturer & 683 & 57 & 14 & 11 & $36,703,054$ & $17,600,000$ & $54,303,054$ \\
\hline $\begin{array}{l}\text { Assistant } \\
\text { Lecturer }\end{array}$ & 488 & 40 & 10 & 8 & $26,224,144$ & $12,800,000$ & $39,024,144$ \\
\hline $\begin{array}{l}\text { Teaching } \\
\text { Assistant }\end{array}$ & 395 & 32.9 & 8 & 6 & $21,226,510$ & $9,600,000$ & $30,826,510$ \\
\hline
\end{tabular}

Table 6 shows the maximum annual, monthly, and weekly teaching load and the maximum number of publications for different categories of non -science Academic staff at Makerere University. Example, a senior Lecturer should teach for a maximum of 15.8 hours per week and publishes a maximum of 12 papers in a year. The proportion of his total remuneration attributable to teaching, $\left(S_{t}\right)$ is $U G X$ 40,034,810 per year and that attributable to research $\left(S_{r}\right)$ is 19,200,000 to give his total remuneration of UGX59, 234,810per year.

According to Makerere University Research and Innovations Policy (2008) section 4.3.1, academic staffs are required to spend at least $20 \%$ of their time on research and dissemination. Suppose we take this proportion of time to be the 
weight, $\beta$ which University assigns to research, such that the weight for teaching, $\alpha=80 \%$. Using these new values of parameters, the results are quite interesting. A science professor would teach for a maximum of 23.8 hours a week and publishes a maximum of 9.6 papers in a year. In practice, this maximum number of publication can be attainable in a University like Makerere where a professor supervises $\mathrm{PhD}$ students' research and co-publishes with them in addition to their own research projects. A Teaching Assistant would teach for a maximum of 12 hours and publishes a maximum of 4.8 papers a year. Similarly, Teaching Assistants can also co-publish with professors who are mentoring them. The mean maximum teaching load is 18.2 hours for all categories of staff. Table 7 provides the maximum teaching load and the maximum number of publications for all categories of academic staff.

Table 7: Workload Summary and Remunerations for Science Professors- With parameter values $\alpha=0.8$ and $\beta=$ 0.2

\begin{tabular}{llllllll}
\hline Title & $\begin{array}{l}\text { Annual } \\
\text { Teachin } \\
\text { g Load }\end{array}$ & $\begin{array}{l}\text { Monthly } \\
\text { Teachin } \\
\text { g Load }\end{array}$ & $\begin{array}{l}\text { Weekly } \\
\text { Teachin } \\
\text { g Load }\end{array}$ & $\begin{array}{l}\text { No. of } \\
\text { Publicatio } \\
\text { n per Year }\end{array}$ & $\begin{array}{l}\text { Annual } \\
\text { Remuneratio } \\
\mathrm{n}\left(S_{t}\right) \\
P_{t} \times T\end{array}$ & $\begin{array}{l}\text { Annual } \\
\text { Remuneratio } \\
\mathrm{n}\left(S_{r}\right) \\
P_{r} \times R\end{array}$ & $\begin{array}{l}\text { Total } \\
\text { Remuneration } \\
S\end{array}$ \\
\hline $\begin{array}{l}\text { Sciences } \\
\text { Professor }\end{array}$ & 1144 & 95 & 23.8 & 9.6 & $\begin{array}{l}51,481,004 \\
57,660,874\end{array}$ & $\begin{array}{l}25,360,000 \\
14,400,000\end{array}$ & $76,841,004$ \\
$\begin{array}{l}\text { Assoc. } \\
\text { Prof }\end{array}$ & 1073 & 89 & 22 & 9 & & & \\
$\begin{array}{l}\text { Senior. } \\
\text { Lecturer }\end{array}$ & 966 & 81 & 20 & 8 & $51,910,908$ & $12,800,000$ & $64,710,908$ \\
$\begin{array}{l}\text { Lecturer } \\
\text { Assistant }\end{array}$ & 877 & 73 & 18 & 7 & $47,128,226$ & $11,200,000$ & $58,328,226$ \\
$\begin{array}{l}\text { Lecturer } \\
\text { Teaching }\end{array}$ & 576 & 46 & 13.6 & 5 & $35,198,390$ & $8,000,000$ & $43,198,390$ \\
Assistant & & 12 & 4.8 & $30,953,088$ & $7,680,000$ & $38,633,088$ \\
\hline
\end{tabular}

Table 7shows the maximum annual, monthly, and weekly teaching load and the maximum number of publications for different categories of science Academic staff if the University assigns a weight of $0.2(\alpha)$ to Research and 0.8 to Teaching $(\beta)$. The purpose of choosing these parameter values was to facilitate comparison of results. With these parameter values, an Associate Professor of science should teach for a maximum of 22 hours per week and publishes a maximum of 9 papers in a year. The proportion of his total remuneration attributable to teaching, $\left(S_{t}\right)$ is $U G X$ $57,660,874$ per year and that attributable to research $\left(S_{r}\right)$ is $14,400,000$ to give his total remuneration of UGX 72,060,874 per year net of tax.

Similarly, with the weights of $20 \%$ attached to research $(\beta=0.2)$ and $80 \%$ attached to Teaching $(\alpha=0.8)$, A nonScience professor would teach for a maximum of 21 hours and publishes a maximum of 8.5 papers a year (Still taking into account co-publishing with graduate students). The maximum teaching load for a non-science Teaching Assistant would be 9.8 hours, with a maximum of 3.9 publications a year (Taking into account co-publishing with their mentors). The average maximum teaching load for all categories of academic staff is 16.3 hours. 
Table 8: Workload Summary and Remunerations for Non-Science Professors- With parameter values $\alpha=0.8$ and $\beta=0.2$

\begin{tabular}{|c|c|c|c|c|c|c|c|}
\hline Title & $\begin{array}{l}\text { Annual } \\
\text { Teachin } \\
\text { g Load }\end{array}$ & $\begin{array}{l}\text { Monthly } \\
\text { Teachin } \\
\text { g Load }\end{array}$ & $\begin{array}{l}\text { Weekly } \\
\text { Teachin } \\
\text { g Load }\end{array}$ & $\begin{array}{l}\text { No. of } \\
\text { Publicatio } \\
\text { n per Year }\end{array}$ & $\begin{array}{l}\text { Annual } \\
\text { Teaching } \\
\text { Remuneratio } \\
\mathrm{n}\left(S_{t}\right) \\
P_{t} \times T\end{array}$ & $\begin{array}{r}\text { Annual } \\
\text { Research } \\
\text { Remuneratio } \\
\mathrm{n}\left(S_{r}\right) \\
P_{r} \times R\end{array}$ & $\begin{array}{r}\text { Total } \\
\text { Remuneration } \\
S\end{array}$ \\
\hline \multicolumn{8}{|l|}{ Non } \\
\hline Sciences & & & & & & & \\
\hline Professor & 1013 & 84 & 21 & 8.5 & $54,436,594$ & $13,600,000$ & $68,036,594$ \\
\hline $\begin{array}{l}\text { Assoc. } \\
\text { Prof }\end{array}$ & 975 & 81 & 20 & 8 & $52,394,550$ & $12,800,000$ & $65,194,550$ \\
\hline $\begin{array}{l}\text { Senior. } \\
\text { Lecturer }\end{array}$ & 890 & 74 & 18.5 & 7 & $47,826,820$ & $11,200,000$ & $59,026,820$ \\
\hline Lecturer & 816 & 68 & 17 & 6.8 & $43,850,208$ & $10,880,000$ & $54,730,208$ \\
\hline $\begin{array}{l}\text { Assistant } \\
\text { Lecturer }\end{array}$ & 582 & 48.5 & 12 & 4.8 & $31,275,516$ & $7,680,000$ & $38,955,516$ \\
\hline $\begin{array}{l}\text { Teaching } \\
\text { Assistant }\end{array}$ & 472 & 39 & 9.8 & 3.9 & $25,364,336$ & $6,240,000$ & $31,604,336$ \\
\hline
\end{tabular}

Table 8shows the maximum annual, monthly, and weekly teaching load and the maximum number of publications for different categories of non -science Academic staff if the University assigns a weight of $0.2(\alpha)$ to Research and 0.8 to Teaching $(\beta)$. The purpose of choosing these parameter values was to facilitate comparison of results.

With these parameter values, as an example, a Lecturer should teach for a maximum of 17 hours per week and publishes a maximum of 6.8 papers in a year. The proportion of his total remuneration attributable to teaching, $\left(S_{t}\right)$ is UGX 43,850,208 per year and that attributable to research $\left(S_{r}\right)$ is 10,880,000 to give his total remuneration of UGX $54,730,208$ per year net of tax.

Results generated by this model are quite similar to the actual practice in some Universities, and seem to be close to the findings of previous research on University Academic staff workload. According to the policy on appointment and promotion of Makerere University (2006), the minimum teaching load for an academic staff is 10 contact hours, and the maximum is 12 hours. The policy however does not segregate teaching loads for academic staff based on their seniority. Therefore, the mean maximum teaching load of 11.46 hours per week for non-science lecturers and 15.2 hours for science lecturers are close to the actual practice at Makerere. The policy also does not explicitly state the number of publications per year for a lecturer. Delello, McWhorter, and Marmion (2018) investigated the Faculty workload (number of hours worked per week) at University of Texas taking into account a wide array of activities such as(1) work-related activities, (2) course preparation and delivery, (3) grading and providing feedback, (4) mentoring, advising and other activities to benefit students, (5) interacting directly with students, (6) responding to email,(7) research activity, and (8) service-related activities. The paper found that lecturers spent on average 37.76 hours per week in teaching-related activities and 9.64 hours per week on research related activities. Moreover, a study conducted by Owuor (2012) which investigated the status of higher education in Kenya, showed evidence of lecturers teaching up to 36 hours in a week. National Council for Higher Education (NCHE) in Uganda describes a teaching load of 10 hours per week as ideal, 15 hours/week as good, 20hours/week as acceptable, 30hours/week as improvable, over 30 hours/week as unacceptable. NCHE encourages University Academic staff to conduct research but does not quantify the required number of publications per lecturer per year. In this result, the maximum teaching load of 27 hours per week (comprising of lecture hours, practical hours, tutorial hours, and students' consultative hours) for a science professor at Lira University appears to be acceptable but not under an ideal situation.

\section{Policy Implications}

Universities should play fundamental roles of social and economic transformation by facilitating the creation and transfer of knowledge between Universities, industry, communities. These mandates require Universities to be very active in both teaching and research. Policy makers should design appropriate mechanisms to enhance professors' ability to conduct research. Specifically, they can consider a reduction in professor's teaching load in order to enhance his ability to publish more papers per year. Policy Makers should also assign appropriate weights to research and teaching as core functions of a professor in the University. These weights are approximated by the government budgetary allocations, or by the number of hours allocated for teaching and research respectively. 
In Australia, the standard practice in many Universities has been the ratio of 40:40:20, that is, $40 \%$ of total allocation (allocation of fund or time) is meant for Teaching, $40 \%$ for Research and 20\% for Administration. While this ratio may not be appropriate for Developing Countries like Uganda because of resource constraint, a weighing scale of $20 \%$ allocation for research and $80 \%$ allocation for teaching seems to produce the most realistic results in practice. This idea is envisaged in Makerere University Research and Innovations Policy (2008) where Academic staffs are encouraged to spend not less than $20 \%$ of their time on research and the rest of their time (80\%) on teaching and other duties. The differential workload system presented in this paper implies adjustments on professors' workload according to the level of their seniority, position, and specialty (Science or non-science). It would not be a good idea to assign the same level of workload to different categories of University academic staff with different salary scales. From economic perspective, a higher salary scale must translate into higher academic productivity measured by the number of publications and teaching loads. Policy makers should ensure there are a clear dividing line between the teaching load and the required research output of a junior academic staff with lower remuneration and a senior academic staff with higher remuneration.

\section{Conclusion}

The author proposed a general solution to professor's optimal workload by using Lagrangian function. University Management is treated as a utility maximizer, whose objective is to efficiently utilize professor's teaching hours and research output. The paper used the Cob-Douglas utility function for this utility maximization problem. This model can be used by any University to approximate the optimal workload of academic staff in the two dimensions of teaching and research, if the following parameters are known or can be estimated accurately: (1) Wage rate per hour (price of one hour of teaching), (2) the cost of publishing a paper (the price that the University pays a professor for publishing one paper), (3) the weight that the university attaches to research relative to teaching, (4) the weigh that the University attaches to teaching relative to research, and (5) Salary scale for different categories of Academic Staff. The data used for this analysis were obtained from policy documents of Lira University and Makerere University in Uganda. The model generated varying maximum levels of teaching loads and research output for different categories of academic staff and faculties (Science and Non-science faculties). Generally, workload increases in both dimensions of teaching and research, as remuneration increases when one is promoted from a lower position, say a senior lecturer, to higher position, say Associate professor. The model also generated higher workload both in teaching and research for the Faculty (Sciences) whose academic staffs are better paid compared to staff in the non-science Faculty who are paid lower remunerations. The paper concludes by suggesting appropriate policy implications.

\section{References}

Basarudin, N. A., Yeon, A. L., Yacoob, N., and Rahman, R. A. (2016). "Faculty Workload and Employment Benefits in Public Universities",International Review of Management and Marketing, Vol.6, No.7, pp 73-82

Delello, McWhorter, and Marmion (2018), "Understanding the productivity of faculty members in higher education" International Journal of Management in Education, Vol.12, No. 2, pp154

Dobele, A.Thiele, S.R, Kopanidis, F. and Steel, M (2010). "All things being equal: observing Australianindividual academic workloads" Journal of Higher Education Policy and Management, Vol. 32, No. 3, June 2010, 225237

Houston, D. Meyer, L. and Paewai, S. (2006), "Academic Staff Workloads and Job Satisfaction: Expectations and Values in Academe", Journal of Higher Education Policy and Management, Vol. 28, No.1, pp 17-30

Houston, D. Meyer, L.H, and Paewai,S.(2006). "Academic Staff Workloads and Job Satisfaction: Expectations and values inacademe" Journal of Higher Education Policy and Management, Vol. 28, No. 1, March 2006, pp. 1730

Hughes, J.L. and McGarrity, J.P (2012). "The Optimal Allocation of Faculty across Colleges of Business", International Journal of Business, Humanities and Technology Vol. 2 No. 7

Khan, M.A. (2017), 'Achieving an Appropriate Balance between Teaching and Research in Institutions of Higher Education: An Exploratory Study’ International Journal of Information and Education Technology, Vol.7, No5. Pp341-349.

Kim, H. andRehg, M.(2018). "Faculty Performance and Morale in HigherEducation: A Systems Approach"Systems Research and Behavioral Science, Vol. 35, pp308-323

Makerere University (2006), "The Policy on Appointment and Promotion of Academic Staff as Reviewed and Approved by the University Council and Amended at the 112th Meeting of University Council held on 10th September 2009” 
Martin, B.R. 2012. "Are Universities and University Research under Threat? Towards an Evolutionary Model of University Specialization."Cambridge Journal of Economics. Vol.36, No 3: pp543-565.

Minter, R. L. (2009),"Faculty burnout",Contemporary Issues in Education Research, Vol.2, No.2, pp1-8

Muriisa,R.K. (2015). "Rethinking the Role of Universities in Africa: Leadership as a Missing Link in Explaining University Performance in Uganda"JHEA/RESA Vol. 12, No 1, 2014, pp. 69-92

Mushemeza E.D (2016), "Opportunities and challenges of academic staff in higher education in Africa", International Journal of Higher Education, Vol.5, No.3, pp236-246.

National Council for Higher Education (2014), 'Quality Assurance Framework for Universities and the Licensing Process for Higher Institution’ Government of Uganda, Kampala

Nikolioudakis, N. Tsikliras,A.C., Somarakis,S. and Stergiou,K.(2015), "Tenure and AcademicDeadwood" Ethics in Science And Environmental Politics, Vol. 15: 87-93

Okpara, J. O.,Squillace, M, Erondu, E. A., (2005). "Gender differences and job satisfaction: a study of university teachers in the United States". Women Manage. Rev. Vol.20, No.3, pp177-190

OlogundeAO,Akindele RI, Akande (2013), "Moonlighting among university lecturers and their performance in the South-Western Nigeria",Journal of Management and Sustainability. Vol.3, No.4, pp92-102.

Owuor, N. A., 2012, 'Higher Education in Kenya: The Rising Tension between Quantity and Quality in the PostMassification Period', Higher Education Studies, vol. 2(4), pp. 126-136

Owuor,N.A. (2012), 'Higher Education in Kenya: The Rising Tension between Quantity and Quality in the PostMassification Period' Higher Education Studies; Vol. 2, No. 4; 2012

Rubenstein, H. (2000). "Rewarding University Professors: A Performance-Based Approach" A Fraser Institute Occasional Paper

World Bank and Elsevier (2014),"A Decade of Development in Sub-Saharan African Science, Technology, Engineering \& Mathematics Research" A Report by the World Bank and Elsevier 